\title{
Chemical Composition and Antioxidant Properties of Essential Oils from Peppermint, Native Spearmint and Scotch Spearmint
}

\author{
Zhaohai Wu ${ }^{1,2}$, Bie Tan ${ }^{1,3}$, Yanhong Liu ${ }^{1}$, James Dunn ${ }^{4}$, Patricia Martorell Guerola ${ }^{5}$, \\ Marta Tortajada ${ }^{5}$, Zhijun Cao ${ }^{2}$ and Peng Ji ${ }^{6, * \mathbb{D}}$ \\ 1 Department of Animal Science, University of California, Davis, CA 95616, USA \\ 2 State Key Laboratory of Animal Nutrition, College of Animal Science and Technology, \\ China Agricultural University, Beijing 100193, China \\ 3 Key Laboratory of Agro-ecological Processes in Subtropical Region, Institute of Subtropical Agriculture, \\ Chinese Academy of Sciences, Changsha 410125, China \\ 4 Applied Nutrition, ADM Animal Nutrition, Quincy, IL 62305, USA \\ 5 Cell Biology Laboratory, ADM Biopolis, 46980 Valencia, Spain \\ 6 Department of Nutrition, University of California, Davis, CA 95616, USA \\ * Correspondence: penji@ucdavis.edu; Tel.: +1-530-752-6469; Fax: +1-530-752-0175
}

Received: 26 June 2019; Accepted: 30 July 2019; Published: 2 August 2019

check for updates

\begin{abstract}
Natural antioxidants have drawn growing interest for use in animal feed and the food industry. In the current study, essential oils (EOs) obtained from hydrodistillation of three mentha species, including Mentha piperita (peppermint), Mentha spicata (native spearmint) and Mentha gracilis (Scotch spearmint), harvested in the Midwest region in the United States, were analyzed for their chemical composition using gas chromatography-mass spectrometry, and their antioxidant properties were assessed through chemical assays, in vitro cell culture modeling and in Caenorhabditis elegans (C. elegans). The activity of ferric iron reduction and free-radical scavenging capacity were assessed through chemical-based assays, including the reducing power assay, 2,2-diphenyl-1-picrylhydrazyl (DPPH) radical scavenging assay, and Trolox equivalent antioxidant capacity assay (TEAC). Subsequently, the capacity of EOs to mitigate lipid peroxidation was analyzed at various doses using fresh liver homogenates from pigs. A porcine jejunum epithelial cell line (IPEC-J2) was employed as in vitro model to study the cellular antioxidant activity of the mint EOs. Finally, the effectiveness of mint EOs to alleviate acute systemic oxidative damage were evaluated in vivo using C. elegans. Data were analyzed by the MIXED procedure of SAS. Contrast statement was performed to assess linear or quadratic effects of mint EOs given at various doses. All three EOs are mostly composed of monoterpenes and their derivatives (76-90\%), but differed in the major compounds, which are menthol and menthone (50\%) in peppermint EO and carvone $(70 \%)$ in spearmint EOs. Three mint EOs demonstrated prominent radical scavenging and $\mathrm{Fe}^{3+}$ reducing activity in chemical-based assays. In comparison with native and Scotch spearmint EOs, peppermint EO had the lowest $(p<0.05)$ half maximal effective concentration (EC50) in DPPH and TEAC assays and higher efficacy in the reducing power assay. All three EOs exhibited equivalent activity in mitigation of chemical-induced lipid peroxidation in liver tissues in a dose-dependent manner (linear, $p<0.001$ ). The maximal cellular antioxidant activity (CAA) was observed at $5 \mu \mathrm{g} / \mathrm{mL}$ for peppermint, and $100 \mu \mathrm{g} / \mathrm{mL}$ for native and Scotch spearmint EOs. The addition of $25 \mu \mathrm{g} / \mathrm{mL}$ of both spearmint EOs increased $(p<0.05)$ cellular concentrations of glutathione in $\mathrm{H}_{2} \mathrm{O}_{2}$-treated IPEC-J2 cells, suggesting enhanced endogenous antioxidant defense. Supplementation of $100 \mu \mathrm{g} / \mathrm{mL}$ of peppermint or Scotch spearmint EO significantly increased $(p<0.05)$ the survival rate of $C$. elegans in response to $\mathrm{H}_{2} \mathrm{O}_{2}$-induced oxidative stress. The protective effect is comparable to that of supplementation of $10 \mu \mathrm{g} / \mathrm{mL}$ of ascorbic acid. However native spearmint EO failed to reduce the death rate within the same supplementation dose $(10-200 \mu \mathrm{g} / \mathrm{mL})$.
\end{abstract}


Keywords: antioxidant activity; essential oil; spearmint; peppermint

\section{Introduction}

Intracellular reactive oxygen species (ROS) are normally present at low concentrations as byproducts of mitochondrial respiration and have beneficial effects on cellular processes. However, excessive ROS exposure causes oxidative damage to the lipid membrane, protein and DNA, which may lead to cell death and tissue injury [1,2]. The epithelial layer of the gastrointestinal tract is susceptible to oxidative damage as it is frequently exposed to noxious environmental factors (e.g., oxidized dietary constituents and pathogens). A large number of resident immune cells aligned with the gut epithelium is another significant source of ROS. Moreover, the insults from environmental stress factors (i.e., heat-stress) also heighten the production of ROS in enterocytes and compromises barrier function of gut epithelium in animals and humans [3-6]. In the livestock industry, oxidative stress has been recognized as one of the major threats to animal welfare, productive performance and the quality of animal products $[3,7,8]$. Feed use antioxidants is not only an effective approach to prevent autoxidation of dietary constituents but also a promising strategy to mitigate enteric oxidative stress in animals. Due to the consumer resistance to synthetic antioxidants (i.e., butylated hydroxytoluene, butylated hydroxyanisole and ethoxyquin) [9-11], identification of natural antioxidants has drawn growing interest.

Essential oils (EOs) are liquid mixtures of volatile compounds that are commonly collected through steam distillation of aromatic plants. Essential oils have been reported for their beneficial biological functions including antiviral, antimicrobial, anti-inflammatory as well as antioxidant effects [12-15]. In spite of tremendous chemical diversity, most essential oils contain compounds that belong to two structural families, namely terpenoids and phenylpropanoids [16]. Both families consist of a large number of phenolic compounds that vary in their antioxidant activities [17]. Environmental factors and maturity of the plants have been shown to significantly the composition of EOs, and thus alter their antioxidant capacities. Therefore, it is critical that chemical profiles are analyzed when the antioxidant activities of EO products are compared. In general, phytochemicals act as antioxidants through several modes of action that involve: (1) retarding the formation of and/or scavenging free radicals; (2) chelating redox-active metals; (3) enhancing endogenous anti-oxidative defense and (4) reducing autoxidation [18-20].

Mentha (mint) is a genus of an aromatic perennial herb belonging to Lamiaceae family [21]. The peppermints (Mentha $\times$ piperita L.) and two species of spearmints, 'Scotch' spearmint (Mentha $\times$ gracilis Sole) and 'Native' spearmint (Mentha spicata L.) are among the most important crops in EO production worldwide, and have been widely used as flavors in food, toothpaste, pharmaceuticals and cosmetics [22]. Owing to the abundant content of phenolic compounds [23,24], aqueous extracts and EO from mint plants are potential natural antioxidants $[25,26]$. For instance, peppermint EO was found to be an effective alternative short-term treatment of irritable bowel syndrome in humans, of which the effect is considered to be mediated through its antioxidant and anti-inflammatory activities [27]. However, many studies that have assessed the antioxidant activities of mint Eos have exclusively relied on chemical-based assays, whereas the effectiveness of mint EOs in prevention of oxidative stress at cellular level or in a living organism have not been clearly characterized. This study aimed to thoroughly evaluate antioxidant properties of EOs collected from peppermint, native spearmint and Scotch spearmint using 3-tiered analyses, namely chemical assays, in vitro cell culture modeling and in vivo animal modeling in Caenorhabditis elegans. The general antioxidant activities in terms of iron reduction and free radicals scavenging were analyzed through chemical-based assays. The capacity of mint EOs in mitigating lipid peroxidation was subsequently determined at various doses using freshly collected pig liver homogenates. Then, a porcine jejunal epithelial cell line was used as an in vitro 
model of intestinal epithelium to assess the cellular and intracellular antioxidant functions of mint EOs. Finally, nematode, Caenorhabditis elegans, was used to validate antioxidant activity of EOs in vivo.

\section{Results and Discussion}

\subsection{Chemical Composition of Mint EOs and Total Phenolic Compounds}

Substantial differences in chemical composition and abundance were observed between peppermint and the two spearmint EOs (Table 1). Peppermint EO consisted of high amounts of menthol $(38.45 \%)$, menthone (21.8\%), 1,8-cineole (5.62\%), and neo-menthol (4.19\%, Table 1), which altogether represented $70 \%$ of non-polar compounds identified. Our results are consistent with other studies, wherein menthol and menthone were the most abundant constituents in peppermint EO [28,29]. Both Native and Scotch spearmint EOs are rich in carvone, a monoterpene ketone that is responsible for the aroma and the beneficial effects of the spearmint EOs [30]. In the current study, carvone (70.36 and $70.91 \%$ in native and Scotch spearmint EO, respectively) was the predominant compound followed by limonene (6.96 and 13.96\%). Buleandra et al. [31] also reported the same primary compounds in the EOs of peppermint and spearmint harvested in Romania, but the concentration of carvone in the spearmint EO was only 51.7\%. Both peppermint and spearmint are temperate plants and require long days for deposition of EO constituents. Therefore, geographical site and leaf maturity at harvest considerably affect chemical composition of mint EOs and their bioactivities including antioxidant capacity [31-33]. A wide range of carvone content (49.6\% to 76.6\%) was reported for EOs of spearmint harvested from 26 sites in the North_west Himalayan region of India [33]. In essential oil, it is believed that some unsaturated terpenes (i.e., terpinenes), monocyclic terpenes (i.e., thymol) and monoterpenes (i.e., limonene, 1,8-cineole, and carvone) contribute to the antioxidant activity [34].

Table 1. Composition of non-polar constituents (peak area\%) in mint essential oils (EO).

\begin{tabular}{|c|c|c|c|c|}
\hline Compounds ${ }^{1}$ & $\begin{array}{l}\text { Retention } \\
\text { Time, min }\end{array}$ & $\begin{array}{c}\text { Peppermint } \\
\text { EO, } \%\end{array}$ & $\begin{array}{c}\text { Native Spearmint } \\
\text { EO, } \%\end{array}$ & $\begin{array}{c}\text { Scotch Spearmint } \\
\text { EO, } \%\end{array}$ \\
\hline Tricyclene & 13.23 & -2 & 0.1 & 0.05 \\
\hline alpha-Pinene & 14.03 & 0.56 & - & - \\
\hline 1-Octen-3-ol & 15.8 & 0.11 & - & - \\
\hline Sabinene & 15.91 & 0.43 & 0.48 & 0.46 \\
\hline beta-Pinene & 16.16 & 0.81 & 0.62 & 0.59 \\
\hline 3-Octanol & 16.82 & 0.26 & 1 & 2.68 \\
\hline beta-Myrcene & 16.87 & 0.2 & 2.41 & 0.56 \\
\hline alpha-Terpinene & 18.41 & 0.35 & 0.16 & - \\
\hline para-Cymene & 18.6 & 0.32 & 0.22 & - \\
\hline 1,8-Cineole & 19.07 & 5.62 & 2.24 & 1.32 \\
\hline Limonene & 19.31 & 1.58 & 6.6 & 12.99 \\
\hline cis-beta-Ocimene & 19.53 & 0.34 & 0.2 & - \\
\hline gamma-Terpinene & 20.91 & 0.56 & 0.36 & 0.05 \\
\hline trans-Sabinene Hydrate & 21.15 & 0.86 & 1.1 & 0.14 \\
\hline alpha-Terpinolene & 22.81 & 0.18 & 0.12 & - \\
\hline cis-Sabinene Hydrate & 23.04 & 0.11 & 0.16 & 0.09 \\
\hline Linalool & 23.21 & 0.37 & 0.09 & 0.07 \\
\hline Amyl Isovalerate & 23.83 & 0.15 & - & - \\
\hline 3-Octanol Acetate & 24.84 & 0.05 & 0.32 & 0.13 \\
\hline trans-Pinocarveol & 25.66 & - & 0.09 & 0.13 \\
\hline trans-Verbenol & 26.02 & - & - & 0.11 \\
\hline Menthone & 26.33 & 21.8 & - & 1.21 \\
\hline Isomenthone & 26.91 & 3.75 & - & 0.16 \\
\hline Menthofuran & 27.41 & 2.08 & - & - \\
\hline neo-Menthol & 27.56 & 4.19 & - & - \\
\hline 4-Terpineol & 28.25 & - & 1.09 & 0.19 \\
\hline Menthol & 28.59 & 38.45 & 0.12 & - \\
\hline
\end{tabular}


Table 1. Cont.

\begin{tabular}{|c|c|c|c|c|}
\hline Compounds ${ }^{1}$ & $\begin{array}{l}\text { Retention } \\
\text { Time, min }\end{array}$ & $\begin{array}{c}\text { Peppermint } \\
\text { EO, } \%\end{array}$ & $\begin{array}{c}\text { Native Spearmint } \\
\text { EO, \% }\end{array}$ & $\begin{array}{c}\text { Scotch Spearmint } \\
\text { EO, \% }\end{array}$ \\
\hline iso-Menthol & 28.78 & 0.71 & - & - \\
\hline cis-Dihydrocarvone & 28.88 & - & 0.99 & 0.94 \\
\hline alpha-Terpineol & 29 & - & 0.29 & 0.2 \\
\hline neoiso-Menthol/alpha-Terpineol & 29.21 & 0.41 & - & - \\
\hline trans-Dihydrocarvone/Dihydrocarveol & 29.29 & - & 0.44 & 0.11 \\
\hline neo-Dihydrocarveol & 29.52 & - & 0.26 & - \\
\hline trans-Carveol & 31.4 & - & 0.68 & 0.53 \\
\hline Piperitone & 32.86 & 0.65 & 0.26 & 0.31 \\
\hline Pulegone & 31.83 & 0.91 & - & - \\
\hline Carvone & 32.59 & - & 70.36 & 70.91 \\
\hline Carvone Oxide (1st Isomer) & 33.25 & - & 0.07 & 0.14 \\
\hline Carvone Oxide (2nd Isomer) & 33.97 & - & 0.16 & 0.25 \\
\hline neo-Menthyl Acetate & 34.96 & 0.22 & - & - \\
\hline Thymol & 35.66 & 0.1 & - & - \\
\hline Menthyl Acetate & 36.05 & 3.9 & - & - \\
\hline iso-Menthyl Acetate & 37.03 & 0.19 & - & - \\
\hline Dihydrocarvyl Acetate & 38.12 & - & 0.17 & - \\
\hline Eugenol & 39.33 & 0.05 & 0.13 & 0.11 \\
\hline cis-Carvyl Acetate & 40.24 & - & 0.7 & 0.12 \\
\hline cis-Jasmone & 41.71 & 0.03 & 0.44 & 0.37 \\
\hline beta-Bourbonene & 42.73 & 0.43 & 1.69 & 1.36 \\
\hline beta-Elemene & 43.05 & 0.23 & 0.15 & 0.08 \\
\hline beta-Caryophyllene & 44.8 & 2.87 & 1.1 & 0.88 \\
\hline beta-Copaene & 45.37 & 0.07 & 0.25 & 0.18 \\
\hline trans-beta-Farnesene & 46.88 & 0.49 & 0.97 & 0.44 \\
\hline Phenethyl Isovalerate & 47.62 & - & 0.16 & 0.23 \\
\hline Germacrene D & 48.47 & 3.24 & 1.01 & 0.5 \\
\hline Bicyclogermacrene & 49.33 & 0.53 & - & - \\
\hline alpha-Muurolene & 49.52 & - & 0.48 & 0.49 \\
\hline delta-Cadinene & 50.78 & 0.16 & 0.05 & 0.06 \\
\hline Viridiflorol & 54.51 & 0.8 & 0.45 & - \\
\hline
\end{tabular}

\subsection{Chemical-Based Antioxidant Activity Assays}

The antioxidant effects of phytochemicals generally act through scavenging free radicals, chelating divalent metals, donating hydrogen or electron, and facilitating decomposition of peroxyl radicals, thus they could retard the formation of free radicals, slow or inhibit autoxidation process (chain-breaking antioxidant), or expedite the termination of autoxidation. A myriad of studies have revealed the potent antioxidant effects of EOs extracted from aromatic plants [16].

In the current study, free-radical scavenging capacity of mint EOs was assessed through the 2,2-diphenyl-1-picrylhydrazyl (DPPH) radical scavenging assay. A dose-dependent increase of radical scavenging activity was observed in all mint EOs (Figure 1A) and the maximum response was reached at the highest concentration $(500 \mathrm{mg} / \mathrm{mL})$ of each mint EO. Peppermint EO had the lowest EC50 compared to both spearmint EOs $(p<0.05$, Table 2), while the EC50 of Scotch EO was greater than that of native spearmint EO $(p<0.05)$. These results indicated the strongest radical scavenging activity of peppermint EO.

The 2,2'-azinobis [3-ethylbenzothiazoline-6-sulfonic acid]-diammonium salt (ABST) cation in Trolox equivalent antioxidant capacity (TEAC) assay has been widely used to determine antioxidant property with respect to the hydrogen-donating and chain breaking activities [35], which is expressed as Trolox equivalent in the current study. As shown in Figure 1B, the slopes of the curves were continuously decreased with the increase of concentration of mint EOs. Plateau was reached at $200 \mathrm{mg} / \mathrm{mL}$ for all three products (Figure 1B). In agreement with the DPPH assay, peppermint EO exhibited the lowest EC50 $(p<0.05)$, suggesting the strongest ABST cation scavenging activity (Table 2). 
Free radical chain reactions can be terminated by a hydrogen or electron donor, and the precursors of peroxide can be removed by reductants [35]. Reducing power assay evaluates the capacity of electron donation of mint EOs by measuring the effectiveness in reducing ferric iron to its ferrous form [36]. With the increased concentration, all three mint EOs displayed increased reducing power (Figure 1C), which reached a plateau at $200 \mathrm{mg} / \mathrm{mL}$ (Figure 1C). Although the EC50 was not statistically different among three mint EOs, the maximum capacity of ferric iron reduction was the highest in the peppermint EO.

As expected, all three mint EOs exhibited consistent anti-oxidative activity across different chemical-based tests. These observations were in agreement with studies in which the antioxidant activity of the mint EOs were observed and attributed to the major monoterpenoids including menthol, menthone, carvone and 1,8-cineole [37-39]. Other minor constituents in mint EOs that contain substances in the active methylene group, such as terpinolene, $\alpha$ - and $\gamma$-terpinene, were also reported for their strong antioxidant activity, which is comparable to $\alpha$-tocopherol [17]. However, results from chemical-based assays should be interpreted with caution. Lack of standardized protocol in chemical assays results in inconsistent outcomes from different studies [40]. Furthermore, the concentration of mint EOs used in chemical assays may not be practical in biological systems. In particular, chemical assays can neither elucidate the bioactivities of different phytochemicals nor measure the indirect antioxidant activity (i.e., alter intracellular antioxidant enzymes) in a living organism. Therefore, we further evaluated antioxidant activities of mint EOs in fresh tissue homogenates, cell-based tests and in vivo model using C. elegans.

Table 2. Antioxidant activity of essential oils (EOs) of peppermint, native spearmint, and Scotch spearmint, measured by chemical-based antioxidant activities assays.

\begin{tabular}{cccc}
\hline \multirow{2}{*}{ Assay $^{\mathbf{1}}$} & \multicolumn{3}{c}{ EC50, $\mathbf{~ m g} / \mathbf{m L}$} \\
\cline { 2 - 4 } & Peppermint EO & Native Spearmint EO & Scotch Spearmint EO \\
\hline DPPH scavenging capacity & $70.29 \pm 4.59^{\mathrm{c}}$ & $86.51 \pm 5.45^{\mathrm{b}}$ & $109.8 \pm 6.70^{\mathrm{a}}$ \\
TEAC assay & $29.51 \pm 1.30^{\mathrm{b}}$ & $45.74 \pm 1.71^{\mathrm{a}}$ & $44.38 \pm 1.67^{\mathrm{a}}$ \\
Reducing power assay & $22.7 \pm 1.66$ & $23.39 \pm 2.66$ & $22.91 \pm 2.35$ \\
\hline
\end{tabular}

\footnotetext{
$\mathrm{a}, \mathrm{b}, \mathrm{c}$ Within a row, means without a common superscript letter are different $(p<0.05)$. Data are least squares means of 6 observations per treatment. ${ }^{1}$ TEAC $=$ Trolox equivalent antioxidant capacity, FRAP $=$ ferric reducing antioxidant power, EC50 = half maximal effective concentration, DPPH = 2,2-diphenyl-1-picrylhydrazyl.
}
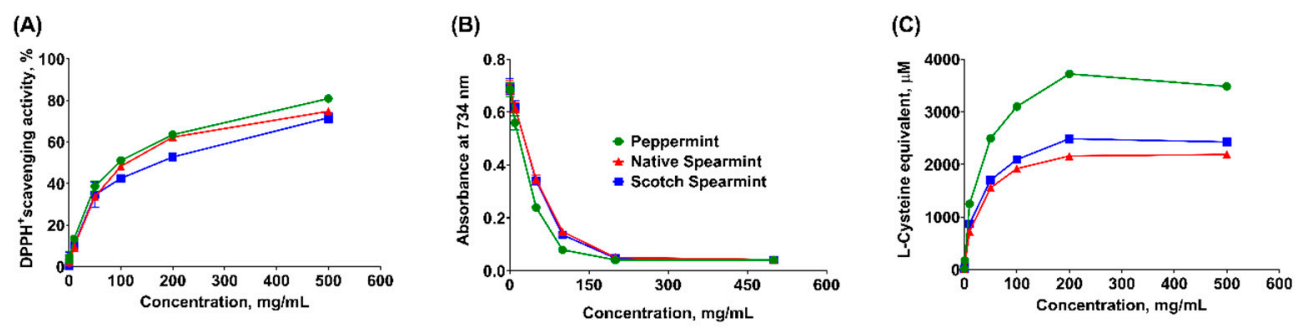

Figure 1. Dose response of mint essential oils using chemical-based antioxidant capacity assays. (A) 2,2-diphenyl-1-picrylhydrazyl (DPPH) radical scavenging activity assay, (B) Trolox equivalent antioxidant capacity (TEAC) assay, and (C) Reducing power assay. Data are least squares means of 6 observations per treatment.

\subsection{Lipid Peroxidation Assay}

Lipid peroxidation is a process that oxidants (i.e., free radicals) attack lipids containing unsaturated fatty acids and generate lipid peroxyl radicals and hydroperoxides. The lipid layer(s) of the cellular membrane is critical in maintaining cell permeability and physiological homeostasis, but also vulnerable to lipid peroxidation which, if uncontrolled, may lead to cell death and tissue injury. The liver is the major metabolic organ that is particularly susceptible to lipid peroxidation damage. In the current experiment, we assessed the inhibitory effects of mint EOs on chemical-induced lipid peroxidation in 
fresh liver homogenates (Figure 2). All mint EOs similarly reduced (linear, $p<0.001$ ) lipid peroxidation in a dose-dependent manner. The strongest inhibitory effect was observed at $1000 \mu \mathrm{g} / \mathrm{mL}$ for all mint oils. There was no further reduction of lipid peroxidation when mint oils were used at $2000 \mu \mathrm{g} / \mathrm{mL}$. It has been reported that natural phenolic compounds (i.e., tocopherols) behave as pro-oxidants at high concentrations [41], which may explain the diminished inhibitory effect of mint oils on lipid peroxidation at $2000 \mu \mathrm{g} / \mathrm{mL}$ in the current study.

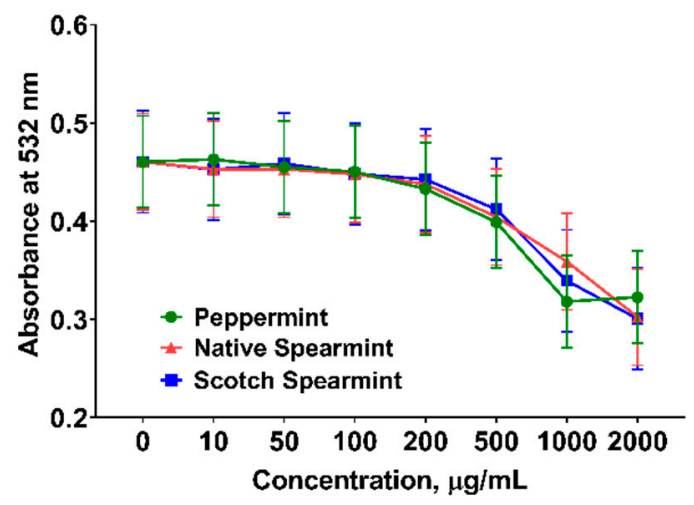

Figure 2. Inhibition of chemical-induced lipid peroxidation in pig liver homogenates by essential oils. Essential oils of peppermint, native spearmint, and Scotch spearmint dose dependently reduced (linear, $p<0.001$ lipid peroxidation in liver. No differences were observed among 3 mint oils. Data are least squares means of 4 observations per treatment.

\subsection{Cellular-Based Antioxidant Activity Assay}

The intestinal epithelial layer is constantly exposed to oxidative challenges (e.g., oxidized feed and pathogens), and thus is susceptible to oxidative damage. In-feed use of antioxidants should also be effective in mitigation of epithelial oxidative stress. Hence, a porcine jejunal epithelial cell line (IPEC-J2) was used as an in vitro model to assess cellular antioxidant activity (CAA) of mint EOs. Prior to the CAA assay, the cytotoxicity of mint oils on IPEC-J2 cells was evaluated at various concentrations using of 3-(4,5-dimethylthiazol-2-yl)-2,5 diphenyltetrazolium bromide (MTT) assay. As shown in Figure 3, there was significant reduction in cell viability when the concentration of mint EOs reached $200 \mu \mathrm{g} / \mathrm{mL}$. Essential oils of different mentha species had shown cytotoxic effects on cancer cells (e.g., gastric cancer SGC-7901, lung carcinoma SPC-A1, prostate cancer cells) as reported in other studies [32,42]. In addition, essential oil of Mentha piperita L. had shown moderate toxicity on larvae of Artemia salina ( $\mathrm{LC}_{50}$ of $414.6 \mu \mathrm{g} / \mathrm{mL}$ ) [43]. However, few studies have reported cytotoxic effects on gut epithelial cells.

Testing cellular antioxidant activity is biologically more meaningful than chemical-based antioxidant assays [44,45]. Dichlorofluorescin (DCF) is a probe that can be easily taken up by cultured cells. In the presence of intracellular peroxyl radicals, DCF will be oxidized to fluorescent dichlorofluorescein. The capacity of mint EOs to remove experimentally-induced intracellular peroxyl radicals and inhibit the formation of fluorescent DCF directly correlates with the antioxidant property of EOs [44]. In other words, the cumulative fluorescent signals quantified as area under curve (AUC) during the reaction period is negatively correlated with the antioxidant capacity of mint EOs. Supplementation of all three mint EOs in culture media significantly decreased the AUC $(p<0.05)$ compared to non-supplemented control samples, suggesting the protective effect of mint EOs against cellular oxidative damage (Figure 4). The cellular antioxidant effects of mint EOs was comparable to that of Trolox, a water-soluble analog of vitamin E. However, the maximum inhibition occurred at different concentration for each mint oil. Peppermint oil had maximal inhibitory effect when supplemented at $5 \mu \mathrm{g} / \mathrm{mL}$, whereas the maximal inhibitory effect was not observed in spearmint and Scotch oil until the concentration increased to $100 \mu \mathrm{g} / \mathrm{mL}$. The fact of compromised cellular antioxidant effects with higher concentration of EOs further supported that the pro-oxidant activity of mint EOs is 
concentration dependent. Unsaturated terpenes, such as linalool, $\gamma$-terpinene and $\alpha$-pinene, are subject to autoxidation and generate reactive alkyl radical that bears pro-oxidant activity $[16,17]$. The higher contents of linalool and $\gamma$-terpinene in peppermint than the other two EOs might contribute to the greater pro-oxidant action of peppermint EO. Chen et al. [46] also reported that low doses of carvacrol $(107$ and $214 \mu \mathrm{M})$ reduced oxidative stress in Caco-2 cells, but high doses of carvacrol $(460 \mu \mathrm{M})$ increased ROS level in those cells.

(A)

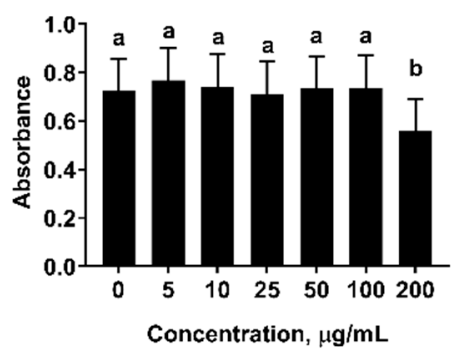

(B)

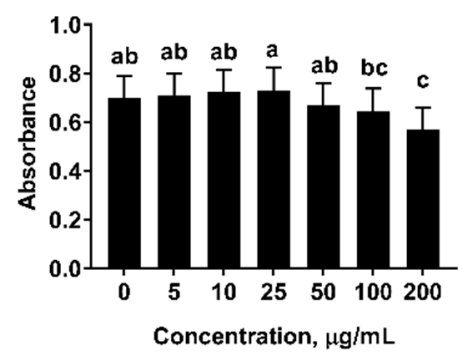

(C)

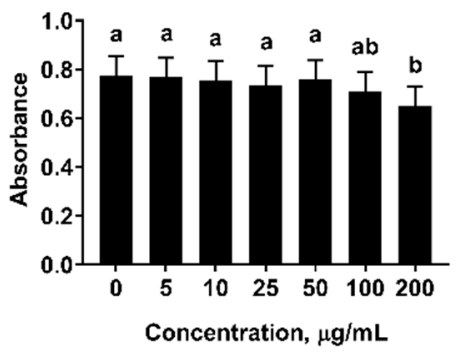

Figure 3. Effects of mint essential oils (EOs) on cell viability of porcine epithelial cells (IPEC-J2) in vitro. (A) Peppermint EO, (B) Native spearmint EO, and (C) Scotch spearmint EO. Data were expressed as least squares means of 6 observations. Values without common letter were significantly different $(p<0.05)$.
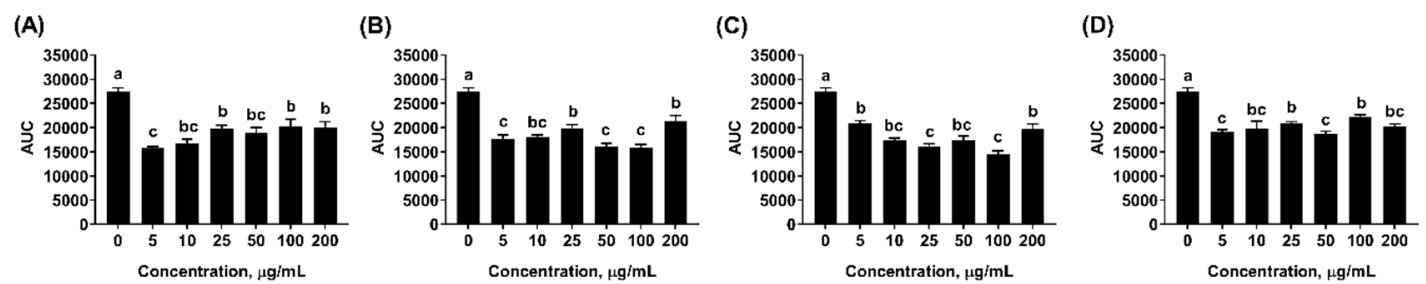

Figure 4. Cellular antioxidant activities of mint essential oils. Total area under curve (AUC) was computed using Trapezoid rule based on kinetic fluorescence data. The lower AUC indicated greater cellular anti-oxidative activity. (A) Peppermint EO, (B) Native spearmint EO, (C) Scotch spearmint EO, and (D) Trolox. Data were expressed as least squares means of 6 observations. Values without common letter were significantly different $(p<0.05)$.

Intracellular Antioxidant Activity Assay

Glutathione (GSH) acts as an electron donor to directly scavenge free radicals or provides a substrate for glutathione peroxidase and glutathione $S$-transferase [47]. Glutathione (GSH) is oxidized to glutathione disulfide, an oxidoreduction process that quenches the intracellular free radicals associated with lipid hydroperoxide and hydrogen peroxide. The concentration of cellular GSH had significant bearing with total antioxidant capacity of cells. Aherne et al. [48] and O'Sullivan et al. [49] reported that sage and seaweed extracts which are rich in flavonoids increased the GSH content in Caco-2 cells. Based on the cell viability results and CAA results, an optimal dose of each mint oil $(25 \mu \mathrm{g} / \mathrm{mL})$ and Trolox $(1 \mu \mathrm{M})$ was selected to conduct the intracellular antioxidant activity (IAA) assay. Hydrogen peroxide, a chemical inducer of cellular oxidative stress, significantly increased GSH concentration in IPEC-J2 cells than that of negative control $(p<0.05)$, highlighting the activation of protective response to neutralize $\mathrm{H}_{2} \mathrm{O}_{2}$-induced ROS. Supplementation of mint EOs and Trolox further increased $(p<0.05)$ cellular GSH, as well as glutathione disulfide (GSSG) concentration in $\mathrm{H}_{2} \mathrm{O}_{2}$-stimulated cells with the exception of peppermint EO (Figure 5). The effectiveness of both spearmint and Scotch EOs was comparable to that of Trolox. Similarly, Zou et al. [50] also observed that oregano mint EO elevated the expression of GSH in IPEC-J2 cells. The higher amount of GSSG in spearmint and Trolox treated cells might be resulted from increased conversion of GSH. However, neither mint EOs nor Trolox significantly changed the cellular GSSG:GSH ratio in $\mathrm{H}_{2} \mathrm{O}_{2}$-stimulated 
cells compared to positive controls $\left(\mathrm{H}_{2} \mathrm{O}_{2}\right.$-stimulated cells). Unexpectedly, peppermint EO did not enhance GSH production, despite its superior antioxidant activity in chemical-based assays and overall effectiveness in mitigating cellular oxidative stress in vitro. Our finding is in contrast to the result of another study, wherein peppermint EO showed a prominent protective effect against carbon tetrachloride-caused hepatotoxicity in rats, as mediated through increasing the activity of superoxide dismutase (SOD) and GSH [51]. Analysis of antioxidant effectiveness of individual EO compounds revealed moderate antioxidant index of the main components of peppermint (menthol and 1,8-cineole) and the two spearmint EOs (carvon and limonene), but low antioxidant capacity of menthone [17].

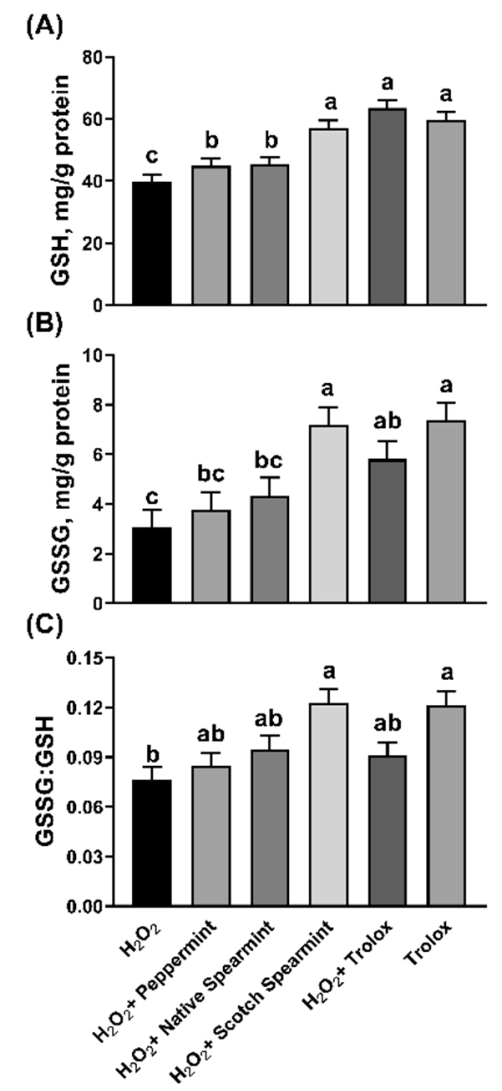

Figure 5. Effects of mint essential oils on the intracellular oxidation state of glutathione. IPEC-J2 cells were pre-treated with or without $25 \mu \mathrm{g} / \mathrm{mL}$ of mint oils or $1 \mu \mathrm{M}$ of Trolox and incubated with $0.5 \mathrm{mM}$ of $\mathrm{H}_{2} \mathrm{O}_{2}$. Concentration of clutathione (GSH, A), oxidized glutathione/glutathione disulphide (GSSG, B) and GSH to GSSG ratio $(\mathbf{C})$ in cell lysates were analyzed. Data were expressed as least squares means of 4 observations. Values without common letter were significantly different $(p<0.05)$.

\subsection{In Vivo Antioxidant Analysis with Nematode Model}

In the light of well-characterized endogenous antioxidant defense and short lifespan ( 30 days), the nematode C. elegans is a widely-used animal model in the study of the antioxidant and antiaging effects of phytochemicals [52-54]. The presence of high concentrations of pro-oxidants (e.g., $\left.\mathrm{H}_{2} \mathrm{O}_{2}\right)$ and redox cycling chemicals (e.g., paraquat) have been shown to shorten the lifespan and increase mortality of $C$. elegans $[55,56]$. In the current assay, all worms were challenged with $\mathrm{H}_{2} \mathrm{O}_{2}$ to induce acute oxidative stress. Supplementation of $10 \mu \mathrm{g} / \mathrm{mL}$ vitamin $\mathrm{C}$ increased $(p<0.05)$ the survival rate of C. elegans by $18 \%$ compared with positive control (Figure 6). All mint EOs displayed pro-survival effects when supplemented at $100 \mu \mathrm{g} / \mathrm{mL}$, but only peppermint EO enhanced survival rate to the extent that was comparable to $10 \mu \mathrm{g} / \mathrm{mL}$ of vitamin C. Moderate improvements of C. elegans survival $(p<0.05)$ were also observed when peppermint EO were supplemented 25 and $50 \mu \mathrm{g} / \mathrm{mL}$. Although the mechanism behind the beneficial effects was not explored in the current study, peppermint EO has 
shown to revert the chemical-induced hepatotoxicity in rodent as mediated at least partially through its antioxidant properties [51]. Essential oil from Juniperus communis L. also displayed antioxidant and pro-survival effects as tested with $C$. elegans. Such beneficial effects were ascribed to its role in modulating insulin/IGF-1 signaling pathway [57]. It is unknown whether mint EOs function through the same mechanism.

(A)

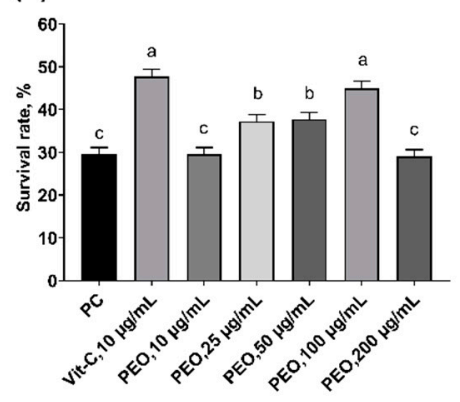

(B)

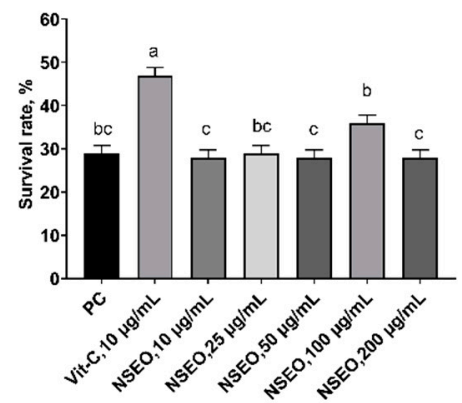

(C)

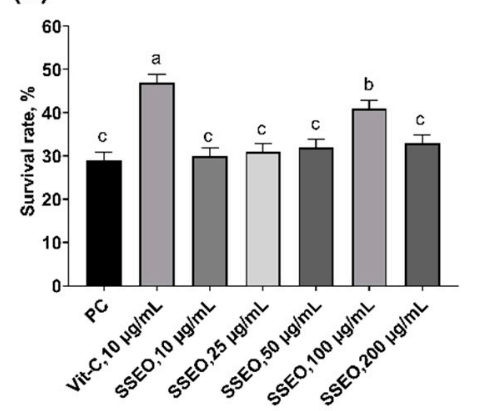

Figure 6. Effects of mint essential oils (EOs) on survival rate of C. elegans in response to $\mathrm{H} 2 \mathrm{O} 2$-induced oxidative stress. The nematode $\mathrm{C}$. elegans were grown in normal medium (PC), or medium containing $10 \mu \mathrm{g} / \mathrm{mL}$ of vitamin C, or different doses $(10,25,50,100$, and $200 \mu \mathrm{g} / \mathrm{mL}$ ) of peppermint EO (PEO, A), native spearmint EO (NSEO, B), and Scotch spearmint EO (SSEO, C). Data were expressed as mean \pm SEM from duplicated trials. Ten replicate plates (10 worms/plate) were performed for each treatment within a trial. Values without common letter were significantly different $(p<0.05)$.

Our study employed multi-tests approach that holistically evaluated antioxidant effects of three mint Eos, including in vitro chemical- and cell-based assays and in vivo tests with C. elegans model. Collectively, all three mint-derived EOs showed significant antioxidant activity in chemical-based assays. The inhibitory effect against lipid peroxidation were comparable among three products. Peppermint EO, however, exhibited greater antioxidant capacity in DPPH, TEAC, and FRAP assays compared to EOs from native spearmint and Scotch spearmint. Furthermore, the maximal CAA response was observed at a much lower dose for peppermint EO $(5 \mu \mathrm{g} / \mathrm{mL})$ than for native or Scotch spearmint EOs $(100 \mu \mathrm{g} / \mathrm{mL})$. Results of IAA assay and in vivo C. elegans survival assays indicate that different cellular mechanisms may be involved in the antioxidant activity of peppermint, native spearmint, and Scotch spearmint EOs. Results of this experiment also suggested the potential use of all three mint EOs as alternative in-feed antioxidant in animal diets. The potential antibacterial effect [58] of mint EO may benefit feed preservation. However, proper processing techniques that could prevent loss of the volatile components of mint EOs is necessary because many of these compounds have antioxidant effects. More research should be conducted to verify the modes of action.

\section{Materials and Methods}

\subsection{Preparation of Mint Essential Oil}

All three mint EOs were provided by ADM Animal Nutrition (Quincy, IL, USA). Mint EOs were produced through hydro-distillation of leaves from peppermint, native spearmint and Scotch spearmint that grew in Midwest region of the US and were harvested before the full flowering stage in summer 2016. The products from initial distillation were re-distilled to removes waxes and sulfur constituents.

\subsection{Analyses of Chemical Composition}

The total phenolic contents of the mint oils were determined using Folin-Ciocalteu reagent, as described by Singleton et al. [59]. Chemical composition (non-polar compounds) of EOs were analyzed by A. M. Todd Company (Kalamazoo, MI, USA) using GC-MS (Agilent 6890N inert gas chromatograph coupled with 5973 mass selective detector system) fitted with a fused silica SPB-1 
non-polar capillary column (length $60 \mathrm{~m} \times 0.25 \mathrm{~mm}$ ID, $0.25 \mu \mathrm{m}$ film thickness; 24030-U, Sigma-Aldrich Co. LLC, St. Louis, MO, USA). Helium (average velocity $26 \mathrm{~cm} / \mathrm{s}$ at constant flow) was used as a carrier gas. The oven temperature was held at $60^{\circ} \mathrm{C}$ for $2 \mathrm{~min}$ and increased to $280^{\circ} \mathrm{C}$ at a rate of $2{ }^{\circ} \mathrm{C} / \mathrm{min}$. Sample $(1 \mu \mathrm{L})$ was injected at $250^{\circ} \mathrm{C}$ with a split/split-less injector (50:1 split ratio). Multiple internal standards were used to normalize chromatographic data. Constituents of mint EOs were identified based on their mass spectra and retention data through library search including HPCH2205 and A.M. Todd databases and in comparison with mass spectra of authentic compounds.

\subsection{Chemical-Based Antioxidant Assays}

Three chemical-based antioxidant assays were performed to evaluate antioxidant activity and free radical scavenging capacity, including DPPH radical scavenging capacity assay, Trolox equivalent antioxidant capacity (TEAC) assay, and reducing power assay. Each mint EO was tested at 0, 1, 10, 50, $100,200,500 \mathrm{mg} / \mathrm{mL}$. Test samples were prepared by diluting the stocking solution with methanol $(w / v)$ with the exception that $80 \%$ ethanol was used to prepare test samples for TEAC assay. All assays were repeated five times (replicates).

\subsubsection{DPPH Radical Scavenging Capacity Assay}

The scavenging capacity of mint EOs against 2,2-diphenyl-1-picrylhydrazyl (DPPH, Sigma, St. Louis, MO, USA) radical was determined based on the method described by Zhou et al. [60]. Briefly, test sample was mixed with DPPH solution $(25 \mu \mathrm{g} / \mathrm{mL}$ in methanol) at a ratio of 1:39 (v/v). Blank sample was prepared by mixing methanol with DPPH solution at the same ratio. The mixture was shaken to mix well and incubated at room temperature for $30 \mathrm{~min}$. At the end of incubation, the absorbance at $517 \mathrm{~nm}$ was read immediately using a Synergy HTX Multi-Mode Microplate Reader (BioTek, Winooski, VT). The scavenging capacity of each mint EO was calculated based on the equation: $\mathrm{DPPH}^{+}$scavenging capacity $(\%)=\left[\left(\mathrm{A}_{\text {blank }}-\mathrm{A}_{\text {test }}\right) / \mathrm{A}_{\text {blank }}\right] \times 100$, where $\mathrm{A}_{\text {blank }}$ was the absorbance of blank sample, and $A_{\text {test }}$ was the absorbance of test sample. Half maximal effective concentrations $(\mathrm{EC} 50, \mathrm{mg} / \mathrm{mL})$ of each mint EO were calculated accordingly. A lower EC50 indicates a higher radical scavenging capacity.

\subsubsection{Trolox Equivalent Antioxidant Capacity Assay}

The assay was performed based on the procedures described by Re et al. [61]. Briefly,

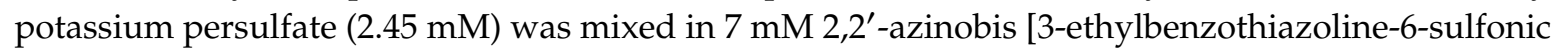
acid]-diammonium salt (ABST; Thermo Fisher, Petaluma, CA, USA) aqueous solution in the dark for $16 \mathrm{~h}$ to generate monocationic radical $\left(\mathrm{ABST}^{+}\right)$solution. The solution was diluted with $80 \%$ ethanol to adjust the absorbance to $0.7( \pm 0.05)$ at $734 \mathrm{~nm}$. The test sample was mixed with $\mathrm{ABTS}^{+}$solution at a ratio of $1: 39(v / v)$. The reactive mixture was allowed to stand at room temperature for approximately 5 min. The absorbance was subsequently measured at $734 \mathrm{~nm}$. Trolox that prepared at different concentrations $(0,0.1,0.5,1,5,10$, and $50 \mathrm{mM})$ were tested to generate standard curve. However, the optical density (OD) results of standard samples of Trolox fitted into a nonlinear curve, wherein the standard samples with concentration above $1 \mathrm{mM}$ maximized the response. Therefore, it is inaccurate to calculate Trolox equivalent of the test samples that yielded OD of maximal response. The EC50 (mg/mL) of each mint EO were calculated based on OD values rather than calculated Trolox equivalent values.

\subsubsection{Reducing Power Assay}

The ferric iron reducing capacity of mint EOs was determined following the procedures by Oyaizu [62] and Oboh and Ademosun [63] with minor modifications. Briefly, equal volume of test sample, $2 \mathrm{M}$ phosphate-buffered saline solution (PBS, pH 6.6) and 1\% potassium ferricyanide (Sigma, St. Louis, MO) were mixed thoroughly. The solution was incubated at $50{ }^{\circ} \mathrm{C}$ for $20 \mathrm{~min}$, and then was added with 10\% trichloroacetic acid (Sigma, St. Louis, MO, USA) at the ratio of 1:3 (v/v) followed by centrifugation at $3000 \times g$ for $10 \mathrm{~min}$. The supernatant was collected and mixed with an equal volume of 
$0.1 \%$ ferric chloride. Absorbance at $700 \mathrm{~nm}$ was measured immediately. L-cysteine prepared at different concentrations $(0,1,5,10,50$, and $100 \mu \mathrm{M})$ were used as the standard samples. The ferric reducing capacity was calculated as L-cysteine equivalent, and the EC50 was calculated for each mint EO.

\subsection{Lipid Peroxidation Assay}

The capacity of mint EOs to mitigate lipid peroxidation were tested at 8 concentrations $(0,10,50$, 100, 200, 500, 1000, and $2000 \mu \mathrm{g} / \mathrm{mL}$ ) following procedure by Oboh et al. [64] with minor modification. Fresh liver samples collected from 4 donor pigs were rapidly processed for lipid peroxidation assays. Liver tissue was firstly homogenized in ice-cold PBS (1:10 w/v) using Telfon tissue grinder. Tissue homogenate was centrifuged at $3000 \times g$ for $10 \mathrm{~min}$ to harvest lipid-containing supernatant. The lipid peroxidation was chemically induced using a mixture of $\mathrm{FeSO}_{4}$ and sodium nitroprusside (MP Biomedicals, Solon, $\mathrm{OH}$ ). Reaction cocktail contains $100 \mu \mathrm{L}$ of supernatants, $30 \mu \mathrm{L}$ of $0.1 \mathrm{M}$ Tris- $\mathrm{HCl}$ $(\mathrm{pH}=7.4), 30 \mu \mathrm{L}$ of $250 \mu \mathrm{M}$ freshly prepared $\mathrm{FeSO}_{4}$, and $70 \mu \mathrm{M}$ sodium nitroprusside and $100 \mu \mathrm{L}$ test samples of mint EO or $1 \times$ PBS (negative control). The final volume was brought to $300 \mu \mathrm{L}$ with water. The reaction cocktail was incubated at $37^{\circ} \mathrm{C}$ for $1 \mathrm{~h}$. Color reaction was developed by adding $300 \mu \mathrm{L} 8.1 \%$ sodium dodecyl sulfate, $600 \mu \mathrm{L}$ of acetic acid (pH 3.4), and $600 \mu \mathrm{L} 0.8 \%$ thiobarbituric acid (Sigma, St. Louis, MO, USA). The mixture was further incubated at $100{ }^{\circ} \mathrm{C}$ for $1 \mathrm{~h}$ and recorded absorbance at $532 \mathrm{~nm}$. Lipid peroxidation adduct of test samples were quantified by comparing the absorbance of the malondialdehyde (MDA) standard curve.

\subsection{Cellular-Based Antioxidant Activity Assay}

\subsubsection{Cell Culture}

Cellular antioxidant activity was tested using porcine intestinal epithelial cell line (IPEC-J2, DSMZ GmbH, Braunschweig, Germany). Cells were cultured at $37{ }^{\circ} \mathrm{C}$ with $5 \% \mathrm{CO}_{2}$ in $\mathrm{HyClone}$ Dulbecco's Modified Eagle Medium (DMEM with $4.5 \mathrm{~g} / \mathrm{L}$ of glucose, Corning, Manassas, VA, USA) supplemented with 10\% fetal bovine serum (Corning, Manassas, VA, USA), and $100 \mathrm{U} / \mathrm{mL}$ of penicillin and streptomycin. Cell culture medium was changed every other day and cells were passaged at $90 \%$ confluence.

\subsubsection{Cell Viability Assay}

Cytotoxicity of mint EOs were firstly assessed using MTT assay following a modified procedure from Liu et al. [15]. Briefly, IPEC-J2 cells were seeded in 96-well plates at a density of $1 \times 10^{4}$ cells/well and incubated at $37{ }^{\circ} \mathrm{C}$ with $5 \% \mathrm{CO}_{2}$ for attachment $(\sim 24 \mathrm{~h})$. Cells were washed and treated with $100 \mu \mathrm{L}$ culture media containing $0,5,10,25,50,100$, or $200 \mu \mathrm{g} / \mathrm{mL}$ of mint EO for $24 \mathrm{~h}$. At the end of treatment, cells were washed, and $100 \mu \mathrm{L}$ DMEM containing 10\% (v/v) of 3-(4,5-dimethylthiazol-2-yl)-2,5 diphenyltetrazolium bromide (MTT, Thermo Fisher, Petaluma, CA) was added to each well. After $2 \mathrm{~h}$ of incubation, medium was replaced by $200 \mu \mathrm{L}$ dimethyl sulfoxide (DMSO, Thermo Fisher, Petaluma, CA). The absorbance was measured at $570 \mathrm{~nm}$ with a reference wavelength at $630 \mathrm{~nm}$.

\subsubsection{Cellular Antioxidant Activity (CAA) assay}

Cellular antioxidant activity of mint EOs were assessed at the concentration of 0, 5, 10, 25, 50, 100, and $200 \mu \mathrm{g} / \mathrm{mL}$ based on the procedure by Li et al. [65]. Briefly, IPEC-J2 cells were seeded $\left(1 \times 10^{5}\right.$ cells/well) in a 96-well plates (black with transparent bottom) at $37{ }^{\circ} \mathrm{C}$ with $5 \% \mathrm{CO}_{2}$ for $24 \mathrm{~h}$. Cells were washed and then treated with $100 \mu \mathrm{L}$ DMEM containing $50 \mu \mathrm{M}$ dichloro-dihydro-fluorescein diacetate (DCFH-DA, Sigma, St. Louis, MO, USA) and mint EO at the proposed concentration for $30 \mathrm{~min}$. After washing with PBS, cells were treated with $100 \mu \mathrm{L}$ of $600 \mathrm{mM}$ 2,2'-azobis(2-methylpropionamidine) dihydrochloride (ABAP) solution to form intracellular peroxyl radicals that oxidize DCFH to the fluorescent DCF. Dynamic fluorescence was measured using a plate reader for 13 cycles at 5 min intervals $(\lambda e x=485$ and $\lambda e m=538)$ and subjected to blank subtraction (cells treated with DCFH-DA 
and PBS without oxidant). The area under the curve (AUC) of fluorescence versus time was integrated to calculate the CAA value of each sample as:

$$
\text { CAA (unit) }=\left(1-\left(\int \mathrm{SA} / \int \mathrm{CA}\right)\right) \times 100
$$

where SA is the area of the test sample (cells treated with mint EO), and CA is the integrated area in the control sample (cells without EO treatment).

\subsubsection{Intracellular Antioxidant Activity (IAA) Assay}

Based on the results of CAA assay, an optimal concentration of each mint EO $(25 \mu \mathrm{g} / \mathrm{mL})$ was selected to perform intracellular antioxidant assay. The IPEC-J2 cells were seeded in cell culture dishes $\left(1 \times 10^{6}\right.$ cells/dish) in $1 \mathrm{~mL}$ DMEM at $37^{\circ} \mathrm{C}$ with $5 \% \mathrm{CO}_{2}$ for $24 \mathrm{~h}$. After washing with $1 \times \mathrm{PBS}$, cells were treated with either DMEM, $1 \mu \mathrm{M}$ Trolox, or $25 \mu \mathrm{g} / \mathrm{mL}$ mint EO and incubated for another $18 \mathrm{~h}$. Cells were further treated with $0.5 \mathrm{mM} \mathrm{H}_{2} \mathrm{O}_{2}$ for $1 \mathrm{~h}$ to induce cellular oxidative stress. Cells previously treated with DMEM were challenged with (positive control) or without $\mathrm{H}_{2} \mathrm{O}_{2}$ (negative control). Finally, cells were scraped off the culture dish, sonicated and deproteinated (subsamples were collected to normalize samples with total protein content before deproteination). Cell lysate was used to analyze the concentrations of glutathione disulfide (GSSG) and total glutathione (GSH) with a commercial Glutathione Assay Kit (Cayman Chemical, Ann Arbor, MI). The ratio of GSSG to GSH was calculated.

\subsection{In Vivo Antioxidant Activity in Caenorhabditis Elegans Model}

\subsubsection{Cultures of Caenorhabditis Elegans (C. elegans)}

The experiment was performed in the research center of Biopolis, S. L. (Valencia, Spain). Wild-type of strain N2 Caenorhabditis elegans was used as an in vivo model to evaluate antioxidant activity of the mint EOs. Nematodes were propagated on nematode growth medium (NGM; contains agar $17.5 \mathrm{~g} / \mathrm{L}$, sodium chloride $3.0 \mathrm{~g} / \mathrm{L}$, peptone $2.5 \mathrm{~g} / \mathrm{L}$, cholesterol $0.005 \mathrm{~g} / \mathrm{L}$ ) at $20^{\circ} \mathrm{C}$ and fed Escherichia coli OP50 that was pre-seeded in the culture medium.

\subsubsection{Oxidative Stress Assays in C. elegans}

In order to obtain synchronous cultures of nematodes, eggs were isolated from gravid adults and hatched overnight in NGM plates. Nematodes were cultured in plain NGM seeded with E. coli OP50 (positive control) or in the medium pre-mixed with vitamin C $(10 \mu \mathrm{g} / \mathrm{mL})$ or each mint EO at different concentrations $(10,25,50,100$ and $200 \mu \mathrm{g} / \mathrm{mL})$. Assays were performed as previously described by Martorell et al. [66]. Synchronized five days old adult nematodes were transferred to a basal medium containing $2 \mathrm{mM} \mathrm{H}_{2} \mathrm{O}_{2}$ and were remained in the medium for $5 \mathrm{~h}$ to induce acute oxidative stress. The survival of worms was observed under magnifying glass. Worms that were unresponsive to prodding were considered dead. Experiments were carried out in duplicates.

\subsection{Statistical Analysis}

Chemical-based assays, in vitro cellular antioxidant tests and in vivo nematode antioxidant tests were replicated for five, three and two times, respectively. Data were analyzed by means of one-way (comparison among conditions within each mint EO samples) or two-way (comparison among EO samples) ANOVA using PROC MIXED of SAS and adjusted for multiple comparison using Tukey's test. Statistical significance and trend were claimed at $p<0.05$ and $0.05 \leq p<0.10$, respectively.

Author Contributions: Conceptualization, Y.L., J.D., and P.J.; study design, Y.L. and P.J.; methodology, Z.W., B.T., Z.C., P.M.G., M.T., Y.L. and P.J.; formal analysis, Z.W., B.T., P.M.G., M.T.; resources, Y.L., P.J. and J.D.; data curation, Z.W., B.T., P.M.G., M.T., Y.L. and P.J.; writing—original draft preparation, Z.W., B.T., Y.L. and P.J.; writing-review and editing, Z.W., B.T., P.M.G., M.T., Z.C., Y.L. and P.J.; visualization, Z.W., Y.L., and P.J.; supervision, Y.L. and P.J.

Funding: This research was supported by NIFA Multistate Research Fund (Project number: CA-D-NTR-2428-RR). 
Conflicts of Interest: The authors declare no conflict of interest. The funders had no role in the design of the study; in the collection, analyses, or interpretation of data; in the writing of the manuscript, or in the decision to publish the results.

\section{References}

1. Valko, M.; Rhodes, C.; Moncol, J.; Izakovic, M.; Mazur, M. Free radicals, metals and antioxidants in oxidative stress-induced cancer. Chem. Biol. Interact. 2006, 160, 1-40. [CrossRef] [PubMed]

2. Pisoschi, A.M.; Pop, A. The role of antioxidants in the chemistry of oxidative stress: A review. Eur. J. Med. Chem. 2015, 97, 55-74. [CrossRef] [PubMed]

3. Shurson, G.C.; Kerr, B.J.; Hanson, A.R. Evaluating the quality of feed fats and oils and their effects on pig growth performance. J. Anim. Sci. Biotechnol. 2015, 6, 10. [CrossRef] [PubMed]

4. Bernabucci, U.; Ronchi, B.; Lacetera, N.; Nardone, A. Markers of oxidative status in plasma and erythrocytes of transition dairy cows during hot season. J. Dairy Sci. 2002, 85, 2173-2179. [CrossRef]

5. Halliwell, B.; Zhao, K.; Whiteman, M. The gastrointestinal tract: A major site of antioxidant action? Free Radic. Res. 2000, 33, 819-830. [CrossRef] [PubMed]

6. Rezaie, A.; Parker, R.D.; Abdollahi, M. Oxidative stress and pathogenesis of inflammatory bowel disease: An epiphenomenon or the cause? Dig. Dis. Sci. 2007, 52, 2015-2021. [CrossRef]

7. Fellenberg, M.A.; Speisky, H. Antioxidants: Their effects on broiler oxidative stress and its meat oxidative stability. World's Poult. Sci. J. 2007, 62, 53-70. [CrossRef]

8. Liang, F.; Jiang, S.; Mo, Y.; Zhou, G.; Yang, L. Consumption of oxidized soybean oil increased intestinal oxidative stress and affected intestinal immune variables in yellow-feathered broilers. Asian-Australas. J. Anim. Sci. 2015, 28, 1194-1201. [CrossRef]

9. Hirose, M.; Takesada, Y.; Tanaka, H.; Tamano, S.; Kato, T.; Shirai, T. Carcinogenicity of antioxidants BHA, caffeic acid, sesamol, 4-methoxyphenol and catechol at low doses, either alone or in combination, and modulation of their effects in a rat medium-term multi-organ carcinogenesis model. Carcinogenesis 1998, 19, 207-212. [CrossRef]

10. Safer, A.M.; Al-Nughamish, A.J. Hepatotoxicity induced by the anti-oxidant food additive, butylated hydroxytoluene (BHT), in rats: An electron microscopical study. Histol. Histopathol. 1999, 14, 391-406.

11. Sun, B.; Fukuhara, M. Effects of co-administration of butylated hydroxytoluene, butylated hydroxyanisole and flavonoids on the activation of mutagens and drug-metabolizing enzymes in mice. Toxicology 1997, 122, 61-72. [CrossRef]

12. Baydar, N.G.; Özkan, G.; Sağdiç, O. Total phenolic contents and antibacterial activities of grape (Vitis vinifera L.) extracts. Food Control 2004, 15, 335-339. [CrossRef]

13. Sökmen, M.; Serkedjieva, J.; Daferera, D.; Gulluce, M.; Polissiou, M.; Tepe, B.; Akpulat, H.A.; Sahin, F.; Sokmen, A. In vitro antioxidant, antimicrobial, and antiviral activities of the essential oil and various extracts from herbal parts and callus cultures of Origanum acutidens. J. Agric. Food Chem. 2004, 52, 3309-3312. [CrossRef] [PubMed]

14. Dundar, E.; Olgun, E.G.; Isiksoy, S.; Kurkcuoglu, M.; Baser, K.H.C.; Bal, C. The effects of intra-rectal and intra-peritoneal application of Origanum onites L. essential oil on 2,4,6-trinitrobenzenesulfonic acid-induced colitis in the rat. Exp. Toxicol. Pathol. 2008, 59, 399-408. [CrossRef] [PubMed]

15. Liu, Y.; Song, M.; Che, T.; Bravo, D.; Pettigrew, J. Anti-inflammatory effects of several plant extracts on porcine alveolar macrophages in vitro. J. Anim. Sci. 2012, 90, 2774-2783. [CrossRef]

16. Amorati, R.; Foti, M.C.; Valgimigli, L. Antioxidant activity of essential oils. J. Agric. Food Chem. 2013, 61, 10835-10847. [CrossRef]

17. Ruberto, G.; Baratta, M.T. Antioxidant activity of selected essential oil components in two lipid model systems. Food Chem. 2000, 69, 167-174. [CrossRef]

18. Djeridane, A.; Yousfi, M.; Nadjemi, B.; Boutassouna, D.; Stocker, P.; Vidal, N. Antioxidant activity of some Algerian medicinal plants extracts containing phenolic compounds. Food Chem. 2006, 97, 654-660. [CrossRef]

19. Lobo, V.; Patil, A.; Phatak, A.; Chandra, N. Free radicals, antioxidants and functional foods: Impact on human health. Pharmacogn. Rev. 2010, 4, 118. [CrossRef]

20. Oh, J.; Jo, H.; Cho, A.R.; Kim, S.-J.; Han, J. Antioxidant and antimicrobial activities of various leafy herbal teas. Food Control 2013, 31, 403-409. [CrossRef] 
21. Arzani, A.; Zeinali, H.; Razmjo, K. Iron and magnesium concentrations of mint accessions (Mentha spp.). Plant Physiol. Biochem. 2007, 45, 323-329. [CrossRef]

22. Bensabah, F.; Houbairi, S.; Essahli, M.; Lamiri, A.; Naja, J. Chemical composition and inhibitory effect of the essential oil from mentha spicata irrigated by wastewater on the corrosion of aluminum in 1 molar hydrochloric acid. Port. Electrochim. Acta 2013, 31, 195-206. [CrossRef]

23. Riachi, L.G.; De Maria, C.A. Peppermint antioxidants revisited. Food Chem. 2015, 176, 72-81. [CrossRef]

24. Naidu, J.R.; Ismail, R.; Yeng, C.; Sasidharan, S.; Kumar, P. Chemical composition and antioxidant activity of the crude methanolic extracts of Mentha spicata. J. Phytol. 2012, 4, 13-18.

25. Dorman, H.J.; Kosar, M.; Kahlos, K.; Holm, Y.; Hiltunen, R. Antioxidant properties and composition of aqueous extracts from Mentha species, hybrids, varieties, and cultivars. J. Agric. Food Chem. 2003, 51, 4563-4569. [CrossRef]

26. Zheljazkov, V.D.; Cantrell, C.L.; Astatkie, T.; Hristov, A. Yield, content, and composition of peppermint and spearmints as a function of harvesting time and drying. J. Agric. Food Chem. 2010, 58, 11400-11407. [CrossRef]

27. Khanna, R.; MacDonald, J.K.; Levesque, B.G. Peppermint oil for the treatment of irritable bowel syndrome: A systematic review and meta-analysis. J. Clin. Gastroenterol. 2014, 48, 505-512. [CrossRef]

28. Oh, J.Y.; Park, M.A.; Kim, Y.C. Peppermint oil promotes hair growth without toxic signs. Toxicol. Res. 2014, 30, 297-304. [CrossRef]

29. McKay, D.L.; Blumberg, J.B. A review of the bioactivity and potential health benefits of peppermint tea (Mentha piperita L.). Phytother. Res. 2006, 20, 619-633. [CrossRef]

30. Salim, R. Carvone content and chemical composition in spearmint (mentha spicata var. viridis 1.) as affected by herb storage under ambient temperature. J. Food Nutr. Popul. Health 2016, 1, 1-5.

31. Buleandra, M.; Oprea, E.; Popa, D.E.; David, I.G.; Moldovan, Z.; Mihai, I.; Badea, I.A. Comparative chemical analysis of mentha piperita and $\mathrm{m}$. spicata and a fast assessment of commercial peppermint teas. Nat. Prod. Commun. 2016, 11, 551-555. [CrossRef]

32. Hussain, A.I.; Anwar, F.; Nigam, P.S.; Ashraf, M.; Gilani, A.H. Seasonal variation in content, chemical composition and antimicrobial and cytotoxic activities of essential oils from four Mentha species. J. Sci. Food Agric. 2010, 90, 1827-1836. [CrossRef]

33. Chauhan, R.S.; Kaul, M.K.; Shahi, A.K.; Kumar, A.; Ram, G.; Tawa, A. Chemical composition of essential oils in Mentha spicata L. accession [IIIM(J)26] from North-West Himalayan region, India. Ind. Crop. Prod. 2009, 29, 654-656. [CrossRef]

34. Clark, R.J.; Menary, R.C. The effect of two harvests per year on the yield and composition of Tasmanian peppermint oil (Mentha piperita L.). J. Sci. Food Agric. 1984, 35, 1191-1195. [CrossRef]

35. Loganayaki, N.; Siddhuraju, P.; Manian, S. Antioxidant activity and free radical scavenging capacity of phenolic extracts from Helicteres isora L. and Ceiba pentandra L. J. Food Sci. Technol. 2013, 50, 687-695. [CrossRef]

36. Teixeira, B.; Marques, A.; Ramos, C.; Neng, N.R.; Nogueira, J.M.; Saraiva, J.A.; Nunes, M.L. Chemical composition and antibacterial and antioxidant properties of commercial essential oils. Ind. Crop. Prod. 2013, 43, 587-595. [CrossRef]

37. Ciftci, O.; Ozdemir, I.; Tanyildizi, S.; Yildiz, S.; Oguzturk, H. Antioxidative effects of curcumin, beta-myrcene and 1,8-cineole against 2,3,7,8-tetrachlorodibenzo-p-dioxin-induced oxidative stress in rats liver. Toxicol. Ind. Health 2011, 27, 447-453. [CrossRef]

38. Ladan Moghadam, A.R. Antioxidant activity and chemical composition of rosmarinus officinalis l. essential oil from iran. J. Essent. Oil Bear. Plants 2015, 18, 1490-1494. [CrossRef]

39. Schmidt, E.; Bail, S.; Buchbauer, G.; Stoilova, I.; Atanasova, T.; Stoyanova, A.; Krastanov, A.; Jirovetz, L. Chemical composition, olfactory evaluation and antioxidant effects of essential oil from Mentha $x$ piperita. Nat. Prod. Commun. 2009, 4, 1107-1112. [CrossRef]

40. Sharma, O.P.; Bhat, T.K. DPPH antioxidant assay revisited. Food Chem. 2009, 113, 1202-1205. [CrossRef]

41. Cillard, J.; Cillard, P.; Cormier, M. Effect of experimental factors on the prooxidant behavior of $\alpha$-tocopherol. J. Am. Oil Chem. Soc. 1980, 57, 255-261. [CrossRef]

42. Sun, Z.; Wang, H.; Wang, J.; Zhou, L.; Yang, P. Chemical composition and anti-inflammatory, cytotoxic and antioxidant activities of essential oil from leaves of mentha piperita grown in china. PLoS ONE 2014, 9, e114767. [CrossRef] 
43. Da Silva Ramos, R.; Rodrigues, A.B.; Farias, A.L.; Simoes, R.C.; Pinheiro, M.T.; Ferreira, R.M.; Costa Barbosa, L.M.; Picanco Souto, R.N.; Fernandes, J.B.; Santos, L.D.; et al. Chemical composition and in vitro antioxidant, cytotoxic, antimicrobial, and larvicidal activities of the essential oil of Mentha piperita L. (Lamiaceae). Sci. World J. 2017, 2017, 4927214. [CrossRef]

44. Wolfe, K.L.; Liu, R.H. Cellular antioxidant activity (CAA) assay for assessing antioxidants, foods, and dietary supplements. J. Agric. Food Chem. 2007, 55, 8896-8907. [CrossRef]

45. López-Alarcón, C.; Denicola, A. Evaluating the antioxidant capacity of natural products: A review on chemical and cellular-based assays. Anal. Chim. Acta 2013, 763, 1-10. [CrossRef]

46. Chen, Y.; Wang, J.; Ou, Y.; Chen, H.; Xiao, S.; Liu, G.; Cao, Y.; Huang, Q. Cellular antioxidant activities of polyphenols isolated from Eucalyptus leaves (Eucalyptus grandis $\times$ Eucalyptus urophylla GL9). J. Funct. Foods 2014, 7, 737-745. [CrossRef]

47. Masella, R.; Di Benedetto, R.; Varì, R.; Filesi, C.; Giovannini, C. Novel mechanisms of natural antioxidant compounds in biological systems: Involvement of glutathione and glutathione-related enzymes. J. Nutr. Biochem. 2005, 16, 577-586. [CrossRef]

48. Aherne, S.A.; Kerry, J.P.; O'brien, N.M. Effects of plant extracts on antioxidant status and oxidant-induced stress in Caco-2 cells. Br. J. Nutr. 2007, 97, 321-328. [CrossRef]

49. O'sullivan, A.; O'Callaghan, Y.; O'Grady, M.; Queguineur, B.; Hanniffy, D.; Troy, D.; Kerry, J.; O’Brien, N. In vitro and cellular antioxidant activities of seaweed extracts prepared from five brown seaweeds harvested in spring from the west coast of Ireland. Food Chem. 2011, 126, 1064-1070. [CrossRef]

50. Zou, Y.; Wang, J.; Peng, J.; Wei, H. Oregano essential oil induces SOD1 and GSH expression through nrf2 activation and alleviates hydrogen peroxide-induced oxidative damage in IPEC-J2 cells. Oxidative Med. Cell. Longev. 2016, 2016, 13. [CrossRef]

51. Mimica-Dukic, N.; Bozin, B. Mentha L. species (Lamiaceae) as promising sources of bioactive secondary metabolites. Curr. Pharm. Des. 2008, 14, 3141-3150. [CrossRef]

52. Khalil, A.F.; Elkatry, H.O.; El Mehairy, H.F. Protective effect of peppermint and parsley leaves oils against hepatotoxicity on experimental rats. Ann. Agric. Sci. 2015, 60, 353-359. [CrossRef]

53. Wilson, M.A.; Shukitt-Hale, B.; Kalt, W.; Ingram, D.K.; Joseph, J.A.; Wolkow, C.A. Blueberry polyphenols increase lifespan and thermotolerance in Caenorhabditis elegans. Aging Cell 2006, 5, 59-68. [CrossRef]

54. Shukla, V.; Yadav, D.; Phulara, S.C.; Gupta, M.M.; Saikia, S.K.; Pandey, R. Longevity-promoting effects of 4-hydroxy-E-globularinin in Caenorhabditis elegans. Free Radic. Biol. Med. 2012, 53, 1848-1856. [CrossRef]

55. Kampkotter, A.; Timpel, C.; Zurawski, R.F.; Ruhl, S.; Chovolou, Y.; Proksch, P.; Watjen, W. Increase of stress resistance and lifespan of Caenorhabditis elegans by quercetin. Comp. Biochem. Physiol. Part B Biochem. Mol. Biol. 2008, 149, 314-323. [CrossRef]

56. Vanfleteren, J.R. Oxidative stress and ageing in Caenorhabditis elegans. Biochem. J. 1993, 292 Pt 2, $605-608$. [CrossRef]

57. Larsen, P.L. Aging and resistance to oxidative damage in Caenorhabditis elegans. Proc. Natl. Acad. Sci. USA 1993, 90, 8905-8909. [CrossRef]

58. Pandey, S.; Tiwari, S.; Kumar, A.; Niranjan, A.; Chand, J.; Lehri, A.; Chauhan, P.S. Antioxidant and anti-aging potential of Juniper berry (Juniperus communis L.) essential oil in Caenorhabditis elegans model system. Ind. Crop. Prod. 2018, 120, 113-122. [CrossRef]

59. Singleton, V.L.; Orthofer, R.; Lamuela-Raventós, R.M. [14] Analysis of total phenols and other oxidation substrates and antioxidants by means of folin-ciocalteu reagent. Methods Enzymol. 1999, 299, 152-178.

60. Zhou, H.-C.; Lin, Y.-M.; Wei, S.-D.; Tam, N.F.-y. Structural diversity and antioxidant activity of condensed tannins fractionated from mangosteen pericarp. Food Chem. 2011, 129, 1710-1720. [CrossRef]

61. Re, R.; Pellegrini, N.; Proteggente, A.; Pannala, A.; Yang, M.; Rice-Evans, C. Antioxidant activity applying an improved ABTS radical cation decolorization assay. Free Radic. Biol. Med. 1999, 26, 1231-1237. [CrossRef]

62. Oyaizu, M. Studies on products of browning reaction: Antioxidative activity of products of browning reaction prepared from glucosamine. Jpn. J. Nutr. 1986, 44, 307-315. [CrossRef]

63. Oboh, G.; Ademosun, A. Characterization of the antioxidant properties of phenolic extracts from some citrus peels. J. Food Sci. Technol. 2012, 49, 729-736. [CrossRef]

64. Oboh, G.; Henle, T. Antioxidant and inhibitory effects of aqueous extracts of Salvia officinalis leaves on pro-oxidant-induced lipid peroxidation in brain and liver in vitro. J. Med. Food 2009, 12, 77-84. [CrossRef] 
65. Li, Q.; Wang, X.; Dai, T.; Liu, C.; Li, T.; McClements, D.J.; Chen, J.; Liu, J. Proanthocyanidins, isolated from Choerospondias axillaris fruit peels, exhibit potent antioxidant activities in vitro and a novel anti-angiogenic property in vitro and in vivo. J. Agric. Food Chem. 2016, 64, 3546-3556. [CrossRef]

66. Martorell, P.; Forment, J.V.; de Llanos, R.; Monton, F.; Llopis, S.; Gonzalez, N.; Genoves, S.; Cienfuegos, E.; Monzo, H.; Ramon, D. Use of Saccharomyces cerevisiae and Caenorhabditis elegans as model organisms to study the effect of cocoa polyphenols in the resistance to oxidative stress. J. Agric. Food Chem. 2011, 59, 2077-2085. [CrossRef]

Sample Availability: Samples of the compounds are available from the authors.

(C) 2019 by the authors. Licensee MDPI, Basel, Switzerland. This article is an open access article distributed under the terms and conditions of the Creative Commons Attribution (CC BY) license (http://creativecommons.org/licenses/by/4.0/). 